\title{
DIVIDEND, INVESTMENT AND LEVERAGE POLICY BASED ON AGENCY THEORY IN INDONESIA MANUFACTURING COMPANIES
}

\author{
H Hersugondo* and Imam Ghozali \\ Diponegoro University, Semarang, Central Java, Indonesia
}

\author{
Eka Handriani \\ Darul Ulum Islamic Centre Sudirman University, Ungaran, Central Java, Indonesia \\ *Corresponding Author
}

\begin{abstract}
The research is aimed to explore Dividend, Investment \& leverage policy based on agency thoeory at manufacturing companies in Indonesia. Having the Agency theory approach such as irving fisher theory and peking order theory using Lisrel software support for 195 manufacturing companies that listed on Indonesia stock exchange of 2014 till 2018 period as samples.

The result shown that Agency cost variable has no significant positive impact towards leverage or on the other words that it has negative impact towards leverage level of the company. Bankcruptcy has a negative effect on the company's leverage level. Investment however has positive effect on the leverage level. Whereas Dividend has a negative impact on company's investment. Dividend gave a positive effect on leverage level and it capable to mediate the investment's effect towards agency cost and leverage level of the enterprise. The outcomes of this trial would bring consequences of the company which has high growth level that requires bigger funds for the investment implementation. Based on pecking order theory, stated that funds requirements should be prioritized on internal fund sources such as retained earnings. Since most of the funds are alocated for the requirement of investment funds, therefore the paid dividend would then reduced. This descriptive proof supported the pecking order theory as this outcomes gave countenance to Fama and French that by using pecking order theory can be simply drawn that debts generally would increased if the investment exceeded the retained earnings, and it would decreased when investment is lower than retained earnings.

This study discusses policies, Dividends, Investment and leverage based on theories such as the Irving Fisher theory and the Peking order theory and research conducted in manufacturing companies in Indonesia which still very rarely reveals this topic and also provides an explanation of this problem using the SEM model.
\end{abstract}


Dividend, Investment and Leverage Policy Based on Agency Theory in Indonesia Manufacturing Companies

Key words: Agency cost, Bankruptcy Cost, Dividend, Investment, Leverage.

Cite this Article: H Hersugondo, Eka Handriani and Imam Ghozali, Dividend, Investment and Leverage Policy Based on Agency Theory in Indonesia Manufacturing Companies, International Journal of Management, 11(12), 2020, pp. 492-510. http://iaeme.com/Home/issue/IJM?Volume=11\&Issue=12

\section{INTRODUCTION}

The Indonesian economic growth continues showing a positive tren that reach above 5\% per annum in average. That was due to the role of manufacturing sector which provide the biggest contribution towards national GDB. Based on the data obtained from Statistic central agency (BPS) mentioned that manufacture industry is remained to present the biggest contribution towards National Bruto Domestic Products (BDP) structure up to 20.07 percent on the first quarter of 2019. That percentage is increased compare to 2018 performance which reached only 19.86 percents.

Then at the same period, the manufacturing sector has contributed up to $22.7 \%$ of the investment worth IDR 195 trillion. It shown that Indonesian economy is continue to be expansive and quite prospective for investors. Having such a potential, Indonesia is considered to become manufacturing hub in ASEAN and production base for global producers to fulfil domestic and export market demands as well. The rating Agency such as Standard and Poor's (S\&P) Global rating has raised the long term debts rating or sovereign credit rating for Indonesia from BBB- to become BBB with stable outlook on 31st of May 2019. Thereby Indonesia now has obtained investment worthy status or investment grade from all three international rating agencies namely, S\&P, Moody's, and Fitch. There would be more fiscal and sector policy forthcoming that facilitated by the government. These strategic efforts are believed to be able to accelerate the growth of industrial and economy to the next level. Indonesia is projected to become the manufacturing center in ASEAN with several industrial sectors that already has in depth structure started from upper course to lower course such as automotive, textile and garment, food and beverage, metal and chemical as well.

On the automotive sector, Indonesia has a great potential since the car production had reached 1.34 millions units last year with USD13.8 billions per annum. At present, there are four major automotive companies that make Indonesia as important player in a global supply chain. In order to support that opportunity the government of Indonesia has arrange some initiatives namely first, Automotive industrial road map to turn them into the biggest vehicle manufacturing with the lowest emission in ASEAN, in particular for Electrified Vehicle (EV) technology. Second, concocting fiscal incentive, for electrified vehicle and to have effective regulations as well, in order to support electrified vehicle industries. Moreover, the government would offer super deductible tax up to $200 \%$ for industries which conducting Research \& Development (R\&D) activities, and plans to create more other opportunities in the coming years. In spite of the fact that at the moment the Indonesian manufacture industries still count heavily on digital however by having a range of regulations issued, the government is trying to balance the more traditional or conventional industries with those wit high technology since the harmony between those two industrial types has a long undergo. As one of the world investment destinations, the government is commiting to continuously boosting the investment by creating a condusive business climate and prepares interesting incentive for the industries. In this research, there are 5 interconnecting variables within investment frame to be discussed, first, agency cost towards investment variable, the cost spent to resolve conflicts that arise between shareholders and managers. This agency costs is considered as an extra costing that must be spent by the company due to arised agency's 
problem. . Second, agency cost towards dividend, the higher the agency cost needed the lower the dividend payment. The asyimmetric information effect on the dividend policy based on pecking order theory, which shown evidence that asyimmetric information is correlating with dividend policy when the investment scale is rising analogously with the debt raise, therefore it encourage shareholders to conduct assets substitution by way of reducing the dividend payment towards retained earnings. On the other hand, when the company facing the over-investment condition due to excessive free cash flow, company should reduce that overinvestment situation on their own. Third, bankruptcy cost that considered as an asyimmetrical information reflection on dividend, company's financial condition that has a potential in bankcruptcy positively correlating with optimum leverage whereas bankcruptcy cost which caused by risk deemed as financial distress that influenced the leverage. Forth, Investment towards dividend, a company with high growth requires bigger funds to implement the investment. Based on pecking order theory, the funds requirement is prioritized on internal funds sources like the retained earnings. Since most of the earnings is allocated for the investment fund requirement, so that the paid dividend is become less. Fifth, Investment towards leverage level, the company complex pecking order model's view has more attention by making financing cost balanced both for present and future time so that enterprises which has high investment opportunity would maintain debt risk capacity to stay low in order to avoid investment funded by new shares emission that has more risks. Sixth, dividend towards leverage level, major companies which has high debt ratio would pay higher dividend. The large amount of dividend payment of the last period would raise cash requirements and encourage higher lending. On the contrary, the more profitable the company the more retained earnings to be use to settle debts so that the residual dividend that has been paid become less. Thereby, according to pecking order theory, there is a relation between dividend and debt ratio.

This research is conducted by testing variables that connecting to one another within company's investment performance frame. Those variables consists of agency cost, dividend, bankcruptcy cost, investment and leverage. The study can contribute to a better academic insights on role of manufacturing enterprise funding in Indonesia by using Lisrel test on 195 corporates as quoted on BEI (Indonesian Stock exchange) financial report. This paper continued as following; the second part is developing hypothesis on inter-variables effect. The third part is about sample and methodology that had been used. On the forth part, we will give our commentary on descriptive statistic, providing the test result and conducting test prior discussion. By the last part, there would be a conclusion of the research.

\section{BACKGROUND THEORY AND HYPOTHESES DEVELOPMENT}

\subsection{Agency Theory View}

Adam Smith had a notion that by maximizing self interest so everyone will provide benefit on society. Individual or group who maximized value and their self interest automatically would create resources allocation at their best. Those individual or group who maximized their value and self interest shall apply efficiency, apart of equality, certainty and convenience principles. According to efficiency principles, maximizing value should be done as efficient as possible and costs that appeared related to maximizing value shall not higher than the benefit value. Adam Smith thought on efficiency principles as part of economic rule, mentioned that all cost spent by individual or group in maximizing value and their self interest should be forced at the lowest level as possible. Ideally, those transaction costs that spent should not burdensome and constraining individual or group in maximizing value. Individual or group have to make choice on combination strategy between activity transaction costs that would eventually give optimum result, which is activities that produce high outcome (strategizing) with cheap 
Dividend, Investment and Leverage Policy Based on Agency Theory in Indonesia Manufacturing Companies

transaction cost (economizing). Considering that individual or group are tend to have an opportunistic and self interested behaviour in doing their option upon combination strategy between activity and transaction cost, therefore all economic exchange would become more efficient if being managed within an official contract or agreement by law between parties who conduct a transaction. Thereby, this efficiency principles would automatically created individual or group to allocate their resources as best as possible.

On the journey of capitalist ethic development and transformation has made agency theory paradigm emerged. It's about how individual or group whose involved in managing an organization to behave in reaching target (maximizing value) glancing with the interest that can turn organization conflict up. Within a workframe of financial management, the agency's relations are available between shareholders and managers, and/or shareholder and creditor. Company's managers may made decisions contradicted with company's goal in maximizing shareholders wealth. The decisions to expand businesses might be urged by manager's desire to create their own division to be more developed with purpose to obtain bigger responsibility and compensations. This conflict is called agency problem.

In a financial academic study, the term of agency cost shown loss that occurred as the impact of agency conflict that happened between the owner (principal) as a mandator with managers (agent) as intermediatery who represents principal in transactions of an entity or organizations. The owner will always contradictory with managers. Managers who always want to reduce expenses post due to their desire in achieving profit target usually being opposed by the owner. Idealy, according to four maxims principle of Smith (1937) that the profit attainment's target does not necessary collide with the owner's interest. If the agency's conflict cannot be avoided, at any circumstances the owner's interest should be prioritized above the manager's interest. In essence, any policy that will be taken by the manager in connection with the interests of the owner must be discussed carefully and comprehensive consideration with shareholders. In the event of an unavoidable conflict of interest, the manager must prioritize the interests of the owner and must be daring to sacrifice the profit achievement target if it must occur, but remain noted to the efficiency principle of economic rule, where the transaction costs incurred are not burdensome and do not hinder the entity manager in pursue the profit achievement targets. The disadvantage of the courage to sacrifice the profit achievement target to accommodate the interests of the owner in the agency relationship is referred to as agency costs. According to Levine (2001), agency costs are extra costs that must be incurred to resolve conflicts that arise between shareholders and managers, such as the costs of supervision and control.

Agency costs can be prevented by utilizing debt, because debt can create an incentive for managers to work harder and make better investment decisions. Financing companies to add new capital through debt, makes managers have to be more careful in using it. Jensen and Meckling (1976) argued that the use of debt can reduce the need for outside stock, and help reduce agency conflict between managers and shareholders. (Jensen 1986; Mao 2003) argued that debt can be used to control the use of excessive free cash flow by managers in negative NPV investment projects that cause inefficiencies in managing the company by management. From this exposure, it appeared that debt policy has an important role in reducing agency conflict.

Agency problems can also be reduced by a dividend payment mechanism. Dividends are the distribution of profits paid to shareholders based on the number of shares held. Decision on dividends is determined by the amount of company profits after tax. In this case, profit after tax is the amount of retained earnings and dividends that will be distributed to shareholders. Therefore, the optimum dividend decision is based on the aim of maximizing 
profits that are shared with shareholders with the constraint of maximizing retained earnings to be reinvested (reinvestment) as a source of internal funds.

Dividend policy plays an important role in determining the value of the company. Shareholders viewed dividends as a signal of a company's ability to increase revenue. For investors, dividends are returns that can be compared with other investment opportunities. This return is called dividend yield, which is the ratio of dividend payments to the price per share. There are a number of opinions that state that the value of the company is not influenced by dividends.

\subsection{Pecking Order Theory}

Modigliani and Miller (1958) explaining the effect of capital structure on company's value. In the perfect capital markets, the capital structure does not influence on company's value. It means that in the irrelevance capital structure theory mentioned that company's value is depending on its asset's capability in creating values, and it would be irrelevant if the assets coming from internal cash or external capital. Modigliani and Miller (1963) take the effect of taxes that must be considered and propose that companies must use as much debt as possible. The company has the advantage of using debt rather than using internal cash, because it can benefit from tax debt. This tax shield allows companies to pay taxes lower than they should, using debt rather than using only their own capital. Jensen and Meckling (1976) had identified agency problems. Conflicts between managers and shareholders lead to equity agency cost, and conflicts between shareholders representing owners and managers. As a result of this conflict agency costs are risen. Usually, managers are interested in achieving their own targets that may be different from the target owners who sometimes cannot increase the value of the company. Owners monitor and control the behavior of these managers. This causes agency costs, with the first assumption, dividend policy is rigid. Managers will try to maintain a constant level of payment. And it would not increase or decrease dividends as a response to current temporary earnings fluctuations. Second, companies prefer internal funding (retained earnings and depreciation) compared to external funding such as debt and shares. Third, if the company obtained external funding, the company would first choose the debt. Fourth, if the company had to use more external funding, the company will choose to use safe debt, then with risky debt, convertible securities, preferred stock and finally the public shares.

(Alipour et al. 2015; DeAngelo and Stulz 2015; Allen et al. 2015; Bertoni et al. 2015; Gornall and Strebulaev 2018) through empirical studies they argued that the strategic effects of capital structure will affect the investment behavior of rival companies where increasing corporate debt is positively correlated with investment decisions and profitability of the company itself, but is estimated to have a negative effect on earnings and investment behavior of rival companies to recapitalize.

Fama and French (2002) in the pecking order theory model shows that companies that have large investments tend to have high funding decisions, where the greater the investment opportunity the greater the company uses external funds, especially debt if internal funds are insufficient. This opinion supports the opinion of Ross (1977) who said that the interaction between investment and capital structure resulted in profitability having a positive effect on funding decisions. However, if it is associated with the Kovenock and Phillips (1997) implicitly, the relationship between the level of funding decisions and company investment will be significant with the existence of industrial organization variables or industry concentration, which is when the industry is increasingly concentrated. 
Dividend, Investment and Leverage Policy Based on Agency Theory in Indonesia Manufacturing Companies

\subsection{The Irving Fisher Theory}

The IrvingFisher theory was introduced in a book entitled Nature of Capital and Income (1906) and Rate of Interest (1907). This theory began to have the most obvious exposition through a book entitled Theory of Interest (1930). (Fisher 1906; Fisher and Barber 1907) explained in the book that corporate investment decisions are a matter of time. Assuming that all capital which used in the production process is capital circulation. In the classic version of the Fisher model, individuals making consumption choices and investment decisions to maximize utilities subject to the constraints of investment decision budgets require a certain amount of funding now and generate revenue based on measures of investment expenditure. Investment decisions will change the distribution of individual temporal income but that can be compensated for by lending activity on the financial market. This is the ability to compensate for income distribution changes.

This theory produces a term known as Fisher's separation, which says that investment decisions are independent of individual preferences for current consumption compared to future consumption. Individuals will choose investment decisions that maximized the present value of their income streams and then choose the combination of optimum consumption by borrowing or lending their funds on the financial market. Of course, the investment return is part of the individual income stream and it become a reasonable consequences of Fisher's separation theorem. The level of investment chosen is one that maximized net present value. Therefore, the consequences in this theorem have become an important part of corporate financial theory that has been used as a theoretical justification for the use of net present value and specifically used as a function of company goals. What is meant by the company's "capital costs", where the funds are used to obtain assets whose results are uncertain; where the capital is obtained from external and internal sources, starting from debt instruments, funding decisions, equity issues, which give shareholders only the right to business certainty? This question has disturbed at least three types of economists: (1) corporate finance managers, which are related to corporate financing techniques to ensure the survival and growth of the company; (2) managerial economists related to capital budgeting; and (3) economic theory related to investment behavior both at the micro and macro level.

\subsection{The Agency Cost Relationship with Leverage}

Ghose and Kabra (2016) had revealed that there was a simultaneous relation between agency cost and investment decision through leverage funding, they shown the evidence that share ownership by management (insider ownership) and share ownership by institution (institutional ownership) tend to encourage reinvestment of profits earned rather than distributing profits in the form of dividends to shareholders. Most of the retained earnings were allocated for investment financing. Conversely, the more widespread public share ownership (asymmetrical information owned by the manager is widening) the greater the demand to pay dividends. When a company faces financial difficulties to finance its investment projects while retained earnings are required to be used for dividend payments, then the company postpones its investment projects.

As explained Fosu, et al., (2016) that agency costs are positively correlated with investment, the study of (Kimathi et al. 2015),(DeAngelo and Stulz 2015). The above explanation confirmed the positive relationship between agency costs (which is proxied by the structure of company asset ownership) and investment, as stated in the formulation of alternative hypothesis 1 which will be tested in this study, as follows

\section{Hypothesis 1: Agency costs have a positive effect on company investment}




\subsection{The Agency Cost Relationship towards Leverage}

Agency problems occured because of the existence of asymmetric information between the owner and manager, that is when one party has information that other party doesn't have. This can lead managers to behave in moral hazard and make expenditures on investments under capital costs (overinvestment) when the free cash flow appeared. These expenses can reduce shareholder wealth. One of the implications of the free cash flow agency problem is that the company's financial performance will be bad and have an impact on the stock market valuation, to reduce agency problems. Jensen and Meckling (1976) and suggested the importance of funding through debt in addition to supervising activities that deviate from management. Debt funding has the potential to reduce agency conflict, because management has an obligation to pay the principal loan along with the interest on the loan. Therefore, the excess cash flow (free cash flow) of the company can be used to settle debt. Thus managers will use debt optimally.

Jensen and Meckling (1976) had opinion that if agency costs are high, the debt ratio will decrease. The results of the study by Jensen et al. (1992), shown that share ownership by management has a negative relationship with the use of debt. Based on the above explanation, an alternative hypothesis can be proposed in this study, as following:

Hypothesis 2: Agency costs negatively affect the company leverage.

\subsection{Bankcrupcy Cost relationship towards Investment}

Bankruptcy costs are the expectation costs of sales risks or losses related to opportunities for bankruptcy and financial failure (financial distress) when companies increase funding through external sources (Favara et al. 2017; Tan and Yang 2016; Lei and Zhang 2016). The cost of bankruptcy expectations when a company borrows money will have an effect on agency cost of debt, previous research has been done by (Allen et al. 2015; Antill and Grenadier 2019; Gornall and Strebulaev 2018; Öztekin 2015) use the concept of bankruptcy costs to express optimization of capital structure. The main problem that is considered when borrowing money is that there would be expected increase in bankruptcy costs. The expected bankruptcy costs depend on the cost of selling losses and the chance of bankruptcy. By the increase of leverage, financial risks and opportunities for financial failure would also increase. Thus bankruptcy costs have a negative effect on investment

Based on the above explanation, an alternative hypothesis can be proposed in this study, as following:

\section{Hypothesis 3: Bankruptcy has a negative effect on company investment}

\subsection{The investment Relationship towards Leverage}

Fama and French (2002) shown that companies which have large investments tend to have high leverage, where the greater the investment opportunity the greater the company uses external funds, especially debt if internal funds are insufficient. This opinion supports the opinion of Ross (1977) who said that the interaction between investment and capital structure resulted in profitability that had a positive effect on leverage. The view of the complex pecking order model Myers (1984) argued that companies are more concerned with balancing current financing costs (financing costs), so companies that have high investment opportunities will maintain a low risk debt capacity to avoid investments funded by new stock emissions that have more risks. This balance of funding costs encouraged companies that have large investment opportunities tend to have high debt ratios. Mao (2003) also revealed that the increase in the scale of investment would increase the volatility of the company's cash flows, this condition would encouraged shareholder's risk-shifting to increase investment funding through debt as long as the risk of debt remained lower than the risk of new shares 
emission. It means that when retained earnings as a source of internal funding are no longer sufficient, the increase in the scale of investment will also increase the funding requirements for investments that will be financed by debt. In other words, investment has a positive effect on the company's debt ratio. In contrast, Mao (2003) explained that when a company adds debt to finance its investment, then marginal investment volatility (MVI) would be increased to the point of the marginal cost of a debt agency equal to the marginal cost of an equity agency. This indicates the level of company leverage has a positive effect on company's investment. Fama and French (2002) shown that companies which had a large investments tend to have a high debt ratio. However, Hennessy and Whited (2005) express the opposite. Based on the above, alternative hypothesis can be postulated in this study as following:

\section{Hypothesis 4: Investment has a positive effect on the level of leverage}

\subsection{The Dividend's relationship towards Investment}

Companies with high growth required more funds to implement their investment. Based on the pecking order theory, funding needs are prioritized on internal funding sources such as retained earnings. Because profits are mostly allocated to investment fund requirements, so the dividends that paid are reduced. Barclay et al. (1998) argued that the determination of funding policies and dividends could not be separated from the problem of the company's free cash flow. Companies that have a high chance of growth are likely to experience difficulties with free cash flow to pay dividends, because the company did not use a lot of resources from outside. Retained earnings as a source of internal funding are mostly allocated to fund investment projects. In this context investment opportunities have a negative effect on dividend payments. Opinion Barclay et al. (1998) is supported by empirical evidence shown by the study of (Adedeji 1998; Pawlina and Renneboog 2005) who find investment decisions negatively affect dividend payments. Fama \& French (2000) also found that companies that do not pay dividends generally have a larger investment projects. Based on the study of (Barclay et al. 1998; Fama and French 2002; Pawlina and Renneboog 2005) it can be postulated an alternative hypothesis 5 regarding the relationship of investment with dividends in this study as following:

\section{Hypothesis 5: Dividends have a negative effect on investment}

\subsection{The Dividends relationship towards Leverage}

Kadioglu and Yilmaz (2017) argue that the determination of funding policies and dividends is inseparable from the issues of the company's free cash flow. Companies that have a high chance of growth are likely to experience difficulties with free cash flow to pay dividends, because the company does not use a lot of resources from outside. Retained earnings as a source of internal funding are mostly allocated to fund investment projects. (Buus 2015; Jensen et al. 1992; Namazi et al. 2016). provide empirical evidence that dividend policy has a negative effect on leverage. Their findings support the agency cost theory. High retained earnings are used to increase dividend payments and pay off company debts. On the other hand, Tong and Green (2005) although not consistent with agency theory, shown the evidence that dividend policy has a positive effect on leverage. High retained earnings are used to pay dividends, while company investment is financed from debt. Another possibility is that retained earnings are used to pay dividends, while debt is added to monitoring costs in an effort to discipline the manager. Moussu and Ohana (2016). This is consistent with the opinion of (Gaver and Gaver 1993; Lei and Zhang 2016; Smith Jr and Watts 1992; Tijjani and Sani 2016) which revealed that dividend payments have a positive effect on the company's debt ratio. Large companies that have high debt ratios pay higher dividends. Large dividend payments in the past period will increase cash requirements and encourage greater borrowing. 
Conversely, the more the profitability of a company the greater the share of retained earnings is used to pay off debt, so that the residual dividends paid are less. Thus, according to pecking order theory there is a positive correlation between dividends and debt ratios (Benavides et al. 2016; Kaźmierska-Jóźwiak 2015). Based on the explanation of Eldomiaty et al. (2017), et al. (2017), alternative hypotheses can be formulated as following:

\section{Hypothesis 6: Dividends have a positive effect on the level of leverage}

\subsection{Investment Mediates the Influence of the Agency on Leverage}

As explained by Jensen (1986), revealed that there was a simultaneous relationship between agency costs and investment decisions, it shows evidence that share ownership by management tends to encourage reinvestment of profits earned rather than distributing profits in the form of dividends to shareholders. Most of the retained earnings are allocated for investment financing. On contrary, the more widespread public share ownership (asymmetrical information owned by the manager is widening) the greater the demand to pay dividends. When a company faces financial difficulties to finance its investment projects while retained earnings are required to be used for dividend payments, the company postpones its investment projects. Their study shown empirical evidence that investment is negatively affected by agency cost. Zeng et al. (2018), suggests that Agency costs are positively correlated with investment, so previous studies have been conducted (Guariglia and Yang 2016). Chen et al. (2016), also confirms the same thing that there is a positive relationship between agency costs and investment, it needs to be tested in this study the hypothesis of the agency cost relationship with investment and leverage, on the company's debt ratio policy, such as the following 7 research of hypothesis postulation :

Hypothesis 7: Investment mediates the effect of agency costs on the level of company leverage.

\section{RESEARCH METHODS}

\subsection{Population and Sample}

Data was obtained from ICMD (Indonesian Capital Market Directory) which observed started from 2014 until 2018. This study uses a sample of 300 company financial statements. Table 1 shows the data used in this study

Table 1 Research Data

\begin{tabular}{|c|c|c|c|}
\hline No & Industry & Company & Observation \\
\hline 1 & Food and Beverage & 10 & 15 \\
\hline 2 & Costomer Good & 4 & 13 \\
\hline 3 & $\begin{array}{c}\text { Metal and Alied } \\
\text { Product }\end{array}$ & 9 & 18 \\
\hline 4 & Cables & 6 & 15 \\
\hline 5 & Paper and Alied & 3 & 5 \\
\hline 6 & Product & 3 & 10 \\
\hline 7 & Ceramic \& Porcelain & 6 & 15 \\
\hline
\end{tabular}


Dividend, Investment and Leverage Policy Based on Agency Theory in Indonesia Manufacturing Companies

\begin{tabular}{|c|c|c|c|}
\hline 8 & Chemical & 10 & 15 \\
\hline 9 & Plastic and Packaging & 7 & 15 \\
\hline 10 & Animal feed & 4 & 10 \\
\hline 11 & $\begin{array}{c}\text { Automotive and } \\
\text { Component }\end{array}$ & 12 & 19 \\
\hline 12 & Textile \& Garment & 10 & 15 \\
\hline 13 & Cigarrette & 3 & 15 \\
\hline 14 & Pharmacy & 7 & 15 \\
\hline & Total & 94 & 195 \\
\hline
\end{tabular}

Source: Processed research Data

Descriptive Statistic had been conducted for this study that explain description on minimum value, maximum value, average value and deviation standard value from Exogenous variables namely Agency cost (Ac), Bankcruptcy cost (Bc), Dividend (Dv) and Endogenous variables namely: leverage (Lev) and Investment (In), Descriptive statistic on research data is completely presented in following table 2 .

Table 2 Deskriptive Statistic of Research Data between 2014 - 2018

\begin{tabular}{|c|c|c|c|c|c|l|}
\hline & $\mathrm{N}$ & Range & Minimum & Maximum & Mean & Std. Deviation \\
\hline $\mathrm{AC}$ & 195 & 216,8434946 & 17,29254712 & 234,1360417 & 85,91099568 & 47,38394658 \\
\hline $\mathrm{BC}$ & 195 & 33,29418826 & $-2,90979606$ & 30,3843922 & 10,5593071 & 6,219606404 \\
\hline $\mathrm{In}$ & 195 & 19,07652062 & 0,507220782 & 19,58374141 & 1,26756655 & 1,48897213 \\
\hline $\mathrm{Dv}$ & 195 & 22,81095746 & 0,851006155 & 23,66196361 & 5,185576862 & 4,108659518 \\
\hline Le & 195 & 0,762269834 & 0,00419077 & 0,766460604 & 0,336151331 & 0,179027725 \\
\hline $\begin{array}{c}\text { Valid N } \\
\text { (listwise) }\end{array}$ & 195 & & & & & \\
\hline
\end{tabular}

Source: Processed Data

\subsection{The Reseach Method}

This study uses path analysis to find out and analyze the influence of exogenous variables on endogenous variables. Path analysis with the aim of explaining the direct and indirect consequences of variables, as the causal variables, towards other variables which are consequent variables.

Some requirements that must be met in the data processing procedures using path analysis are carried out in the following order: 1) relationships between variables are linear and additive; 2) all residual variables do not correlate with each other; 3) the relationship pattern between variables is recursive, namely that the causal relationship is in the same direction; not reciprocal; and 4) Level of measurement of all variables at least intervals. 
Hair et al. (2006) stated that there are four steps that must be taken to use this path analysis, namely: 1) developing the model, which must be done based on theory; 2) developing path diagrams to show causality; 3) conversion of path diagrams into a series of structural equations and measurement model specifications; and 4) selection of input matrices and estimation techniques for the models built. Furthermore, it can be compiled the equation of this research regression

$$
\begin{aligned}
& \text { Lev (Y1): } \\
& \text { Y1 }=\beta_{0}+\beta_{1} \text { Ac }+\beta_{2} \text { In }+\beta_{3} D v+\varepsilon 1
\end{aligned}
$$

\section{Inv (Y2):}

$$
\mathrm{Y} 2=\beta_{0}+\beta_{1} A c+\beta_{2} B c+\beta_{3} D v+\varepsilon 1
$$

\subsection{Definition of Operational Variables}

In this study there are 3 exsogenous variable Agency cost (Ac), Bankcrupcy Cost $(\mathrm{Bc})$, Dividend (Dv). and 2 Endogenous variables: Leverage (Investment) and Investment (In), The following describes the types of variables and how they are measured

Table 3 Research Variables

\begin{tabular}{|l|l|l|}
\hline Variabel & & \multicolumn{1}{|c|}{ Pengukuran Variabel } \\
\hline Agency Cost & AC & $\begin{array}{l}\text { Assets Utilization Ratio (AUR) = Annual Sales / Total } \\
\text { Asset. }\end{array}$ \\
\hline Bankruptcy Cost & BC & standar deviasi EBIT /biaya bunga. \\
\hline Investasi & In & $\begin{array}{l}\text { Total Assets - Total Equity + Market Value of Common } \\
\text { Stocks) / Fixed Assets. }\end{array}$ \\
\hline Dividen & Dv & $\begin{array}{l}\text { Dividend yield / total common stocks + stock's closing } \\
\text { price. }\end{array}$ \\
\hline Leverage & Lev & $\begin{array}{l}\text { Market Value of Leverage = (Total Liabilities) / (Total } \\
\text { Asssets - Total Equity + Market Value of Common Stocks). }\end{array}$ \\
\hline
\end{tabular}

Sumber: penelitian sebelumnya

\subsection{Goodness of Fit Results}

Goodness-of-fit measures the suitability of the observation input (covariance or correlation matrix) with predictions from the proposed model. In this analysis several measures of goodness-of-fit will be used which consist of: First, Chi-Square shows the size of the bad fit of a model. The chi-square value of 0 indicates that the model has a perfect fit. The probability of a deviation between the sample covariance matrix chi square is expected to be insignificant. A significant chi-square value (less than 0.05) indicates that empirical data that has differences with the theory that has been built, and if the probability value is not significant shows empirical data according to the model. If the assumption of normality is fulfilled it will produce two types of Chi-Square namely Minimum Fit Function Chi-Square and Normal Theory Weighted Least Squares Chi-Square. Second, the Goodness of Fit Indices (GFI). Goodness of Fit Indices is a measurement of model accuracy. This GFI test consists of: 
Dividend, Investment and Leverage Policy Based on Agency Theory in Indonesia Manufacturing Companies

(1) Adjusted Goodness of Fit Index (AGFI) is GFI which has adjusted the influence of the degrees of freedom of a model. AGFI value of 1. (2) Root Mean Square Error of Approximation (RMSEA) measures the deviation of the values of meters in a model with a population covariance matrix. The RMSEA value of less than 0.05 indicates a fit model. Confidence intervals to assess the accuracy of the RMSEA estimates must be small, which indicates that RMSEA has good accuracy. (3) Expected Cross Validation Index (ECVI) is used to assess the tendency that a single sample model can be cross-validated if the sample size and population are the same. If the ECVI model value is lower than the saturated ECVI model value and the independence model shows that the model is fit. (4) Akaike's Information Criterion (AIC) and CAIC assess Parsimony's problems in assessing fit models. If the value of AIC is more and CAIC is lower than AIC, the saturated and independence model it means that it has a better fit model. (5) Fit Index is used to determine the model fit. NFI and CFI values range between 0 and 1 . A model is said to be fit if it has a NFI and CFI value greater than 0.9. No-Normed Fit Index (NNFI) is used to overcome problems that arise due to the complexity of the model. Incremental Fit Index (IFI) is used to solve Parsimony problems and sample sizes, and is related to NFI. The IFI cut-off limit is 0.9. While the Relative Fix Index (RFI) is used to measure fit, whose value ranges from 0 and 1 , if the value is greater it indicates a superior fit. The results of testing the goodness of fit model are further drawn in table 4 .

Table 4 The Test Results of Goodness of Fit Model

\begin{tabular}{|c|c|c|c|}
\hline Testing & Mark & Cutt of & Conclusion \\
\hline $\begin{array}{l}\text { Chi-Square dan Probabilitas : } \\
\text { 1. Minimum Fit Function Chi Square } \\
\text { 2. Normal Theory Weighted Least Square Chi } \\
\text { Square }\end{array}$ & $\mathrm{P}=0.050$ & $\mathrm{P}>0,005$ & Model fit \\
\hline Goodness of Fit Indices (GFI) & 3.10 & $\mathrm{P} \geq 0,90$ & Model fit \\
\hline $\begin{array}{l}\text { 1. Adjusted Goodnes of Fit Index (AGFI) } \\
\text { 2. Parsimony Goodnes of Fit Index (PGFI) }\end{array}$ & $\begin{array}{l}0.80 \\
0.90\end{array}$ & $\begin{array}{l}P \geq 0,90 \\
P>0,05\end{array}$ & $\begin{array}{l}\text { Model fit } \\
\text { Model fit }\end{array}$ \\
\hline $\begin{array}{l}\text { 4. Root Mean Square Error of Approximation } \\
\text { (RMSEA) } \\
\text { 5. P-Value for Test of Close Fit (RMSEA) }\end{array}$ & 0.0001 & $<0,050$ & $\begin{array}{l}\text { Model fit } \\
\text { Model fit }\end{array}$ \\
\hline $\begin{array}{l}\text { 1.Expected Cross Validation Index (ECVI) } \\
\text { 2. ECVI for Saturated Model } \\
\text { 3. ECVI for Independence Model }\end{array}$ & $\begin{array}{l}0.28 \\
2,05\end{array}$ & $\begin{array}{l}\text { 4. } \text { ECVI }(0,20)<\text { ECVI for } \\
\text { Saturated }(0,25) \text { Model } \\
\text { 5. ECVI }(0,28)<\text { ECVI for } \\
\text { Independence Model }(2,05)\end{array}$ & $\begin{array}{l}\text { Model fit } \\
\text { Model fit }\end{array}$ \\
\hline $\begin{array}{l}\text { Akaike's Information Criterion (AIC) dan } \\
\text { CAIC : } \\
\text { 1. Model AIC } \\
\text { 2. Independence AIC } \\
\text { 3. Saturated AIC } \\
\text { 4. Model CAIC } \\
\text { 5. Independence CAIC }\end{array}$ & $\begin{array}{c}60.08 \\
48,0 \\
90,00 \\
200 \\
984\end{array}$ & $\begin{array}{l}\text { Model AIC }(60.08)< \\
\text { Independence AIC }(480) \text { dan } \\
\text { Model AIC }(200)<\text { Saturated } \\
\qquad \text { AIC }(311,35) \\
\text { 1. Model CAIC }(76,99)< \\
\text { Independence }(984) \text { Dan } \\
\text { Model CAIC }(200)<\end{array}$ & Model fit \\
\hline
\end{tabular}


H Hersugondo, Eka Handriani and Imam Ghozali

\begin{tabular}{|l|c|c|l|}
\hline 6. Saturated AIC & 300 & Saturated AIC (300) & \\
\hline Fit Index : Normed Fit Index (NFI) & $\mathrm{P}>0,90$ & 0,99 & Model fit \\
Comparative Fit Index (CFI) Incremental Fit & $\mathrm{P}>0,92$ & 0,98 & Model fit \\
Index (IFI) Relative Fit Index (RFI) & $\mathrm{P}>0,90$ & 0,99 & Model fit \\
& $\mathrm{P}>0,90$ & 0.97 & Model fit \\
\hline Sumber : Hasil olah data dengan LISREL
\end{tabular}

\section{RESEARCH RESULT}

\subsection{Survey Result}

Based on the calculation through path analysis Agency cost, Bankcrupcy Cost, Investasi, and Endogenous variables: Leverage and Investment. The next step is to test the hypothesis proposed. The hypothesis result can be seen based on the magnitude of $t$ value on figure 1 .

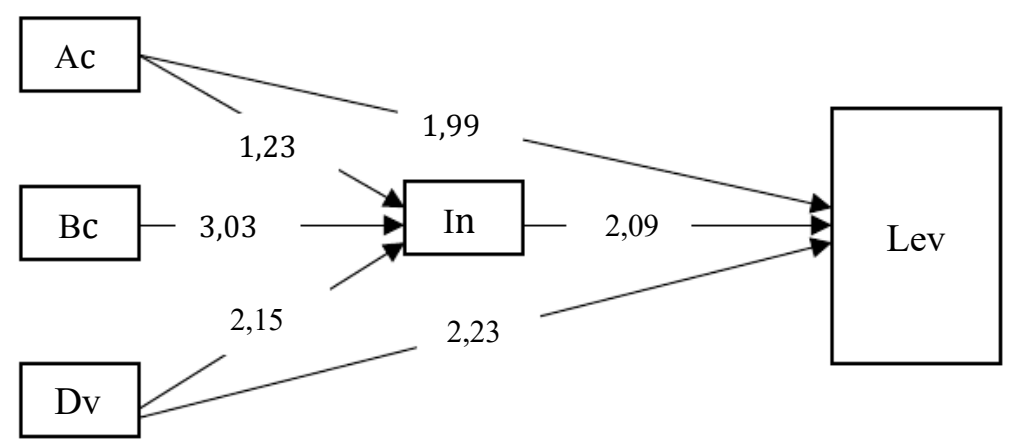

Figure $1 \mathrm{t}$ value

Source: The result of data processing by LISREL

\subsection{Hypothesis Test}

A complete direct effect between variables is presented in table 5 .

Table 5 Direct effect Agency cost, Bankcrupcy Cost, Investasi, dan Investment

\begin{tabular}{|l|c|c|c|l|}
\hline Variable & $\begin{array}{c}\text { Unstandardized } \\
\text { Estimate }\end{array}$ & $\begin{array}{c}\text { Standardized } \\
\text { Coefficient }\end{array}$ & t-Value & Result \\
\hline $\mathrm{Ac} \rightarrow \mathrm{Lev}$ & 0.35 & -0.05 & $1.99^{*}$ & Accepted \\
\hline $\mathrm{Ac} \rightarrow \mathrm{In}$ & 0.26 & 0.04 & 1.23 & Rejected \\
\hline $\mathrm{In} \rightarrow \mathrm{Lev}$ & 0.24 & 0.40 & $2.09^{*}$ & Accepted \\
\hline $\mathrm{Bc} \rightarrow \mathrm{In}$ & 0.36 & -0.28 & $3.03^{*}$ & Accepted \\
\hline $\mathrm{Dv} \rightarrow \mathrm{In}$ & 0.34 & 0.29 & $2.15^{*}$ & Rejected \\
\hline $\mathrm{Dv} \rightarrow$ Lev & 0.25 & 0.36 & $2,23^{*}$ & Accepted \\
\hline
\end{tabular}

Source: The result of data processing by LISREL

Keterangan : *) Signifikan pada $\alpha=5 \%$ 
Dividend, Investment and Leverage Policy Based on Agency Theory in Indonesia Manufacturing Companies

The SEM structure in this study is complete in Figure 2

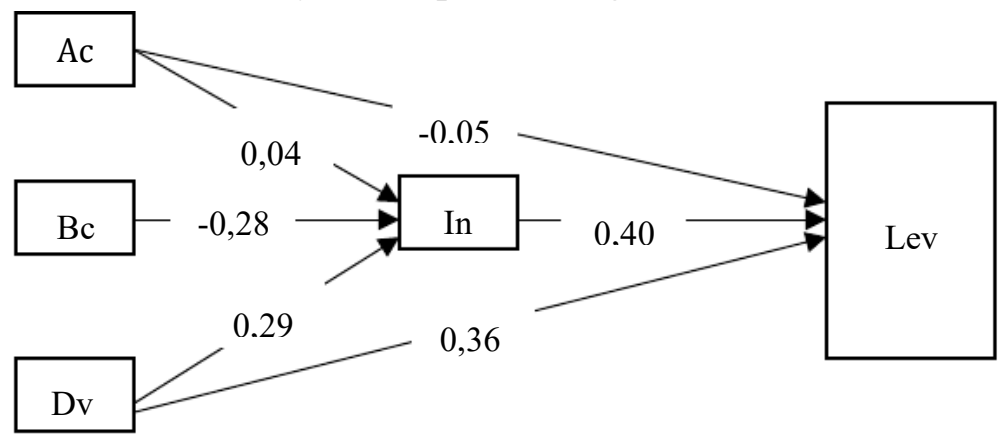

Figure 2 Standardized Value

Source: The result of data processing by LISREL

Table 6 Indirect Influence of Agency Cost, Invesment, dan Leverage

\begin{tabular}{|c|c|c|c|c|c|}
\hline Variable & $\begin{array}{c}\text { Statistical } \\
\text { Test }\end{array}$ & $\begin{array}{c}\text { p } \\
\text { value }\end{array}$ & $\begin{array}{c}\text { Standar } \\
\text { d Error }\end{array}$ & \multicolumn{2}{|c|}{ Result } \\
\hline $\begin{array}{c}\text { Invesment to Agency Cost } \\
\text { to Leverage }\end{array}$ & 2.383 & 0.008 & 0.294 & p value $<0.05$ & Accepted \\
\hline
\end{tabular}

Source: The result of data processing by Sobel Test

\section{CONCLUSION}

Based on the output of the lisrel, the purpose of this study is to test Hypotheses 1 up to 7 as follows, hypothesis 1 aimed to examine the effect of agency cost on the company's investment. The results of testing hypothesis 1 using LISREL indicated that agency cost has a coefficient standardized wit marked positive (0.04) and t value of 1.23 which is smaller than 1.96 at a significance level of 5\%, thus hypothesis 1 which stated the agency cost has an effect positive for the company's investment was proven, but not significant. So this hypothasis 1 is not empirically proven.

Hypothesis 2 which aimed to examine the effect of agency cost on the level of company's leverage. The results of hypothesis 2 testing by using LISREL indicated that agency cost has a coefficient standardized wit marked negative (-0.05) and t value of 1.99 which is greater than 1.96 at a significance level of 5\%, thus hypothesis 2 which states agency cost negative effect on the level of company leverage. Thus hypothesis 2 which states agency cost has a negative effect on the level of company leverage which proven empirically.

Hypothesis 3 which aimed to examine the effect of bankruptcy costs towards company's investment. The results of testing hypothesis 3 using LISREL indicated that the bankruptcy cost has a coefficient standardized marked negative $(-0.28)$ and a $t$ value of 3.03 which is greater than 1.96 at a significance level of $5 \%$, thus hypothesis 3 which stated the bankruptcy cost has a negative effect on investment . Thus hypothesis 3 which stated the bankruptcy cost has a negative effect on the level of company leverage which proven empirically.

Hypothesis 4 which aimed to test the effect of investment towards the level of company's leverage. The results of testing hypothesis 4 using LISREL indicated that firm size has a coefficient standardized with a positive sign (0.40) and a value of $t$ equal to 2.09 which is greater than 1.96 at a significance level of 5\%, thus hypothesis 4 which stated the investment 
firm has a positive effect on the leverage level. Thus hypothesis 4 which stated that investment has a positive effect on the level of company leverage in this study is proven empirically.

Hypothesis 5 which aimed to test the effect of dividends towards the level of company's investment. The results of testing hypothesis 5 using LISREL indicate that dividends have a standardized coefficient marked positive (0.29) and a t value of 2.15 which is greater than 1.96 at a significance level of $5 \%$, thus hypothesis 5 which states dividends has a negative effect on the level of corporate leverage not proven empirically.

Hypothesis 6 which aimed to test the effect of dividends towards the level of company's leverage. The results of hypothesis 6 testing using LISREL indicated that dividends have a coefficient standardized marked positive $(0.36)$ and a $t$ value of 2.23 which is greater than 1.96 at a significance level of 5\%, thus hypothesis 6 which stated dividends has a positive effect on leverage levels company is empirically proven.

Hypothesis 7 which aimed to test the effect of investment mediation on the effect of agency cost on the level of company's leverage. The results of testing hypothesis 7 by using the sobel test get empirical support, as evidenced by the sobel test results obtained $p$ value of 0.008 which is smaller than 0.05 , which means that the role of investment mediation is able to add to the total effect of agency cost and leverage level. This proven empirically that the effect of Agency cost on leverage will be higher if using through this path.

\section{DISCUSSION}

The results of testing hypothesis 1 shown that, the Agency cost had turned out to have a positive and not significant effect on leverage. The results of this study implied that the scale of investment increases in line with the increase in Agency costs, thus encouraging shareholders to substitute assets by reducing investment from retained earnings. On contrary, when a company faces over-investment conditions due to excessive free cash flow, to reduce this over-investment condition, retained earnings should be used to increase investment. This means that to reduce agency conflict between managers and shareholders when the issue of free cash flow arised, it can be done through increased investment. If agency conflict is unavoidable, in any case the owner's interests must be prioritized prioritizing the interests of the manager. In essence, any policy that will be taken by the manager in connection with the interests of the owner must be discussed with careful and comprehensive consideration with shareholders. In the event of an unavoidable collision of interests, the manager must prioritize the interests of the owner and must dare to sacrifice the target of achieving profit if it must occured. The disadvantage of the courage to sacrifice the profit achievement target is to accommodate the interests of the owner in the agency's relationship is referred to as agency costs. Agency costs are extra costs that must be incurred as a result of agency problems, such as monitoring and control costs. According to Levine (2001), agency costs are costs incurred to resolve conflicts that arise between shareholders and managers.

The results of testing hypothesis 2 which stated that agency cost negatively affected the level of leverage of the company is to be empirically proven. The results of this study implied that agency problems occured because of the existence of asymmetric information between shareholders and managers, such as when one party has information that is not owned by the other party. Various ways can be done by managers to have more information than investors, for example by hiding, manipulating information provided to investors. As a result, investors are not sure about the quality of the company and do not want to buy company shares, or buy company shares at very low prices. This condition makes the capital market not properly functioning. Moral hazard occured whenever the manager takes action without the owner's knowledge for his personal benefit and decreasing the owner's welfare. In a relatively large 
Dividend, Investment and Leverage Policy Based on Agency Theory in Indonesia Manufacturing Companies

corporate company with separate ownership and management control, it is difficult for shareholders and creditors to see to what extent of optimum management performance.

The results of testing hypothesis 3 which stated that Bankcrupcy has a negative effect on company's investment which is empirically proven. The results of this study implied that showing Bankcrupcy has a significant negative effect on investment. The results of this test provide evidence that bankruptcy costs have a negative effect on investment. This confirms that investment decisions depend on the expectations of bankruptcy costs. Based on the pecking order stated that the outcomes of poor management performance due to increased volatility of earnings, resulting in companies experiencing difficulties to invest, get additional debt, due to increased opportunities for financial failure (financial distress). Based on the study of (Ahmadpour and Shahsavari 2016; Antill and Grenadier 2019; Antunes et al. 2017; Lin and Dong 2018; Shamsudin and Kamaluddin 2015; Wang et al. 2016).

The results of this study support the pecking order theory. This means that manufacturing sector companies in Indonesia are able to reduce their corporate debt ratio to support investment when earnings volatility (bankruptcy costs) increased.

While in relation to agency theory, Mao (2003) revealed the relationship that occured between earnings volatility and the level of company leverage is positive. This is because logical transitivity negatively influenced earnings volatility on company investment. When shareholders carry out risk shifting, to limit the behavior of managers who deviated from issuing debt, the expectation of bankruptcy costs indicated by increased earnings volatility, resulting in shareholders urged a high dividend payments so that their wealth increases as compensation for the increased risk. This high dividend payment resulted in reduced spending on productive investment projects. High dividend payments can also mean that the company will use debt more to finance its investment, to keep its capital structure optimum.

The results of this study indicatedsufficient evidence to support the agency theory, as stated by Chen et al. (2006) that the debt ratio is increased with the increasing asymmetric information. The possibility of this happened because of differences in interests between insiders (managers) and outsiders (investors) that caused equity agency costs. Issuance of equity will increase the agency agency costs (the need for outside stock increases) thus increasing the potential for agency conflicts between managers and shareholders. To reduce the potential for greater conflict, (Grossman and Hart 1982; Jensen 1986) suggested the use of debt for investment can help limit the conflict. Equity agency costs occured because managers tend to use high debt not on the basis of maximizing company value but for opportunistic interests. Managers have the right to manage the company and investor funds, which allows managers to expropriate investor funds. Addition of debt is used to finance share emissions when the market value of equity is high, or to buy back shares of the company (outside blockholders) when the market value of equity is low. Shleifer and Vishny (1997) suggested another way to suppress these problems through corporate governance, a mechanism that can protect minorities from taking over investor funds by managers and controlling shareholders with an emphasis on legal mechanisms.

The results in testing hypothesis 4 which stated that investment has a positive effect on the level of leverage is to be empirically proven. The results of this study implied that the increased in the scale of investment will also increase the volatility of the company's cash flow, this condition will encourage shareholders to carry out risk-shifting to increase investment funding through debt. When internal funding sources are no longer sufficient, the increase in the scale of investment will increase the funding requirements for investments that will be financed from debt issuance. However, Mao (2003) further explained that when a company adds debt to finance its investment, the marginal volatility of investment will 
increase as well, which means that the company's debt ratio had a positive effect on the company's investment. From this explanation, Mao (2003) stated that there is a positive causality relationship between investment decisions and corporate debt policies. Fama and French (2002) also shown empirical evidence that companies which have large investments tend to have high debt ratios. However, Hennessy and Whited (2005) revealed the opposite that investment opportunities have a negative causality relationship with the debt ratio. The results of the statistical hypothesis testing show that inconclusive investment has a positive effect on the debt ratio for conventional models and structural models of capital structure. Supporting the opinion of Mao (2003), for the case of Indonesian manufacturing companies are generally more on the desire of corporate managers to invest were still adhere to general rules (common factors), wherein the desire to invest increases with increasing size and growth of company assets, but will be decreased when investment risk and collateral value needed to invest (collateral assets) is increased. These results supported the opinion of Fama and French (2002) simple pecking order theory which holds that debt will generally increase when investment exceeds retained earnings, and will decrease when investment is lower than retained earnings. The company's high investment last year was still lower than retained earnings for the current year, making managers limit the use of debt this year. Likewise in the view of the complex pecking order model from Myers and Majluf (1984) the results of this study provided strong evidence that publicly listed companies that are not included in the financial industry and whole sale \& retail trade in Indonesia are more concerned to make balance on funding costs both at present and the future, so that companies that have high investment opportunities will maintain debt risk capacity remains low in order to avoid investments financed by issuing more risky equity. The significance of this study provides recommendations on the importance of companies paying attention to their optimum capital structure as a form of corporate responsibility in the market. By knowing the optimum capital structure of the company, company managers can make investors (shareholders and creditors) as part of the company's empowerment guidelines to place their equity participation in companies that have debt balances and favorable own capital.

The results of testing hypothesis 5 which stated that dividends have a negative effect on investment are not proven empirically. The results of this study implied that optimum dividend decisions are based on the goal of maximizing profits that are shared with shareholders with the constraint of maximizing retained earnings to be reinvested as internal funding sources. Dividend payments will reduce sources of funds controlled by managers, thereby reducing manager's power and making dividend payments. Dividend payments, although they can reduce agency problems, on the other hand create costs. Costs will arise because if the company pays a large dividend, the cash flow generated from internal sources is no longer feasible to meet the company's investment needs. This encourages companies to meet their funding needs from external parties. Companies with high growth need more funds for investment. Based on the pecking order theory, funding needs are prioritized on internal funding sources such as retained earnings. Because profits are mostly allocated to investment fund requirements, the dividends paid are reduced. Barclay et al. (1998) argued that the determination of funding policies and dividends could not be separated from the problem of the company's free cash flow. Companies that have a high chance of growth are likely to experience difficulties with free cash flow to pay dividends, because the company did not use a lot of resources from outside. Retained earnings as a source of internal funding are mostly allocated to fund investment projects. In this context investment opportunities have a negative effect on dividend payments. Opinion Barclay et al. (1998)is supported by empirical evidence shown by the study of (Alstadsæter et al. 2017; Yeo 2018; Ozuomba et al. 2016; Yusof and Ismail 2016) who found investment decisions negatively affected dividend payments. Fama 
and French (2002) also found that companies that do not pay dividends generally have a larger investment projects.

The results of testing hypothesis 6 which stated that dividends have a positive effect on the level of leverage is empirically proven. The results of this study provide the implication that Gordon (1959) concept rethink of two reasons for the important role of dividends in the company's valuation process; the first concept, bird in hand which implied the desire of investors to obtain current income rather than income in the future, and always look for stocks that pay a high constant dividend yield. Investor's anxiety occured when the companies reduced their dividend payments. The second concept, informational content that makes dividends as a signal and confidence in investors that income reinvestment will generate substantially higher dividends in the future. Based on the concept of Gordon (1959), it was shown that dividend payments could increase the value of the company as reflected by the company's stock price. The link between dividend policy and capital structure can be explained from Modigliani and Miller (1958) proposition that if the capital market is imperfect and there are taxes, then the dividends included in the company's valuation will be substituted with the issuance of debt. Thus dividend payments are positively correlated with the debt ratio. This MM proposition is empirically proven by (Cooper and Lambertides 2018; Ghose and Kabra 2016; Kaźmierska-Jóźwiak 2015; Setiawan et al. 2016). High retained earnings are used to pay off corporate debt, thereby reducing the share of retained earnings that can be shared with shareholders in the form of dividends. However, the empirical findings of Jensen et al. (1992) which support the agency cost theory provide evidence that dividend policy has a negative effect on the debt ratio.

The results of testing hypothesis 7 which stated that investment mediates the effect of agency costs, on the level of corporate leverage, is accepted empirically. The results of the study imply that the higher the investment the more significantly reduce dividend payments to shareholders. The decline in dividend payments to shareholders has a significant effect on the increase in the corporate debt ratio. Likewise, although there is no significant negative effect on the ratio of utilization of assets to dividends, a decreased in dividend payments to shareholders is caused by the effect of increasing the asset utilization ratio that will significantly increased the corporate debt ratio. In other words, Reinvestment in this company has a significant impact on reducing dividend payments. This decrease in dividend payments provides an incentive for shareholders to carry out risk-shifting due to the dilution of their wealth. Shareholders put pressure (activism) on management to invest in investment projects that benefit the company. To suppress opportunistic behavior and effectively control the actions of management to manage company assets properly, shareholders increase the company's financing through debt. This increase in corporate financing through debt will encourage caution of management in managing company's assets because of the fixed interest expense that must be paid in addition to the principal loan, in addition to the use of debt can create opportunities for corporate bankruptcy. Thus this finding is consistent with the assumption of agency theory that use to overcome agency problems through debt instruments, shareholders prefer companies that have a low dividend payout ratio because they can maximize company value. This finding shown evidence that the control mechanism carried out by manufacturing companies in Indonesia through dividend policy and corporate debt policy is effectively reduced agency conflict, while also showing evidence that dividend policy is a substitute for debt policy in the corporate capital structure, in accordance with the results of previous research conducted by (Chen et al. 2006; Jensen et al. 1992; Crutchley et al. 1999). 


\section{REFERENCES}

[1] Adedeji, A. Does the pecking order hypothesis explain the dividend payout ratios of firms in the UK? Journal of Business Finance \& Accounting 25 (9-10), 1998, 1127-1155.

[2] Ahmadpour, A., and M. Shahsavari. Earnings management and the effect of earnings quality in relation to bankruptcy level (Firms listed at the tehran stock exchange). Iranian journal of management studies 9 (1),2016, 77-99.

[3] Alipour, M., M. F. S. Mohammadi, and H. Derakhshan. Determinants of capital structure: an empirical study of firms in Iran. International Journal of Law and Management 57 (1),2015, 53-83.

[4] Allen, F., E. Carletti, and R. Marquez. Deposits and bank capital structure. Journal of Financial Economics 118 (3),2015, 601-619.

[5] Alstadsæter, A., M. Jacob, and R. Michaely. Do dividend taxes affect corporate investment? Journal of Public Economics 151,2017, 74-83.

[6] Antill, S., and S. R. Grenadier. Optimal capital structure and bankruptcy choice: Dynamic bargaining versus liquidation. Journal of Financial Economics 133 (1),2019,198-224.

[7] Antunes, F., B. Ribeiro, and F. Pereira. Probabilistic modeling and visualization for bankruptcy prediction. Applied Soft Computing 60,2017, 831-843.

[8] Barclay, M. J., C. W. Smith Jr, and R. L. Watts. The determinations of corporate leverage and dividend policies. The New Corporate Finance. Second Edition, Editor Donald H. Chew, Jr., Malaysia: Irwin Mcgraw-Hill.1998

[9] Benavides, J., L. Berggrun, and H. Perafan. Dividend payout policies: evidence from Latin America. Finance Research Letters 17,2016 197-210.

[10] Bertoni, F., M. G. Colombo, and A. Quas. The patterns of venture capital investment in Europe. Small Business Economics 45 (3), 2015, 543-560.

[11] Buus, T. A general free cash flow theory of capital structure. Journal of Business Economics and Management 16 (3),2015,675-695.

[12] Chen, C. R., W. Guo, and V. Mande. Corporate value, managerial stockholdings and investments of Japanese firms. Journal of International Financial Management \& Accounting 17 (1),2006, 29-51.

[13] Chen, X., Y. Sun, and X. Xu. . Free cash flow, over-investment and corporate governance in China. Pacific-Basin Finance Journal 37,2016, 81-103.

[14] Cooper, I. A., and N. Lambertides. Large dividend increases and leverage. Journal of Corporate Finance 48,2018, 17-33.

[15] Crutchley, C. E., M. R. Jensen, J. S. Jahera Jr, and J. E. Raymond. Agency problems and the simultaneity of financial decision making: The role of institutional ownership. International Review of Financial Analysis 8 (2),1999, 177-197.

[16] DeAngelo, H., and R. M. Stulz. Liquid-claim production, risk management, and bank capital structure: Why high leverage is optimal for banks. Journal of Financial Economics 116 (2),2015, 219-236.

[17] Eldomiaty, T. I., I. Azzam, M. B. El Din, W. Mostafa, and Z. Mohamed. An Empirical Assessment of the Reality of Pecking Order Theory. In Growing Presence of Real Options in Global Financial Markets: Emerald Publishing Limited, 2017, 43-73.

[18] Fama, E. F., and K. R. French. Testing trade-off and pecking order predictions about dividends and debt. The review of financial studies 15 (1)2001, 1-33.

[19] Favara, G., E. Morellec, E. Schroth, and P. Valta. Debt enforcement, investment, and risk taking across countries. Journal of Financial Economics 123 (1),2017, 22-41.

[20] Fisher, I. The nature of capital and income: The Macmillan Company.1906

[21] Fisher, I., and W. J. Barber. The rate of interest: Garland Pub.1907. 